\title{
A Case Study of Smart Grid Station in Guri Branch
} Office of KEPCO

\author{
Jaehong Whang ${ }^{1}$, Woohyun Hwang ${ }^{2}$, Yeuntae Yoo $^{3}$ and Gilsoo Jang ${ }^{3, *}$ \\ 1 Graduate School of Energy and Environment, Korea University, Seoul 02841, Korea; jh_whang@korea.ac.kr \\ 2 Jeju Headquarters, Korea Electric Power Corporation, Jeju-do 63121, Korea; hblue@kepco.co.kr \\ 3 School of electrical Engineering, Korea University, Seoul 02841, Korea; yooynt@korea.ac.kr \\ * Correspondence: gjang@korea.ac.kr Tel.: +82-2-3290-3246
}

\begin{abstract}
Climate change and global warming are becoming important problems around the globe. To prevent these environmental problems, many countries try to reduce the emissions of greenhouse gases (GHG) and manage the consumption of energy. In Korea, Korea Electric Power Corporation (KEPCO) has introduced Smart Grid (SG) technologies to its branch office in 2014. This was the first demonstration of smart grid on a building called Smart Grid Station. This paper treats the achievements of the Smart Grid Station (SGS) by its early target in three aspects. The things are peak reduction, power consumption reduction and electricity fee saving. The authors analyzed the achievements by comparing the data of 2015 with the data of 2014. Through the evaluation, the authors studied the case, proved the advantages of SGS, and suggested the requirements to improve and the direction to go of the system.
\end{abstract}

Keywords: Smart grid, Smart Grid Station, renewable energy sources, energy management system

\section{Introduction}

FOR many years, concerns about global warming and climate change have been growing. In response to these environmental problems, most developed and developing countries have had meetings and looked for countermeasures. One of these efforts resulted in the Kyoto Protocol, an international treaty was adopted in 1997 and took effect in 2005. However, due to the expiration of the Kyoto Protocol in 2020 (Post2020), the Paris Agreement, a statement of intent to address climate change problems, was signed by 195 countries at the twenty-first Conference of the Parties (COP21) of the United Nations Framework Convention on Climate Change (UNFCCC), held in Paris, France, in 2015. The objective of the Paris Agreement was to hold the increase in the global average temperature to below a $2^{\circ} \mathrm{C}$ above pre-industrial levels [1]. Unlike in the case of the Kyoto Protocol, it is significant that many countries attended the COP21 autonomously, and each country set its own target with regard to greenhouse gas (GHG) emissions. Table 1 shows the goals for GHG reduction of some selected countries. Although the United States declared a withdrawal from the agreement, other countries keep trying to contribute to the health of the environment.

Countries that signed the Paris Agreement summited their goals, called Intended Naturally Determined Contribution (INDC), for the reduction of GHG emissions in the Paris Agreement. Through the INDC, the Korean government set a goal to reduce GHG emissions by $37 \%$ compared to business as usual (BAU) by 2030 [5]. As an effort, the Korean government has tried to expand renewable energy generation and develop new technologies. One of the technologies is the Smart Grid (SG), which is a new concept of an electrical grid integrated with information and communication technologies (ICT). The SG is generally composed of distributed energy resources (DERs), such as photovoltaics (PVs) and wind turbines (WTs), Operation System, energy storage 
system (ESS), advanced metering infrastructure (AMI), and other smart devices [6]. The Operation System can balance supply and demand in real time by monitoring and controlling the whole system of a building.

Table 1. Goals of GHG Emissions Reduction for Selected Countries [2-5]

\begin{tabular}{|c|c|}
\hline Countries & Goals \\
\hline China & $\begin{array}{l}\text { To lower carbon dioxide emissions per unit of GDP by } 60 \% \text { to } 65 \% \text { from the } 2005 \\
\text { level }\end{array}$ \\
\hline EU & At least $40 \%$ domestic reduction in GHG emissions by 2030 compared to 1990 \\
\hline Japan & At the level of GHG emission reductions of $26 \%$ by 2030 compared to 2013 \\
\hline South Korea & GHG emission reduction by 37\% from the BAU level by 2030 \\
\hline
\end{tabular}

Since 2009, Korea Electric Power Corporation (KEPCO) which is a public company has installed and demonstrated SG technologies. The Jeju Smart Grid Demonstration Project was the first test-bed built on Jeju Island in 2009. As a comprehensive project, this had five themes: Smart Place, Smart Transportation, Smart Renewable, Smart Power Grid, and Smart Service. It included renewable energy resources, metering, use of electric vehicle, battery system, demand response, transmission, communication, etc. Using the experience gained in the project, Smart Grid Station (SGS) was built in the Guri branch office building of KEPCO in 2014 as the first demonstration on building. Smart Grid Station is a term that combines smart grid with Station. Station means a place or a building that can provide various services. Therefore, Smart Grid Station is a place that provides intelligent electricity services to customers. KEPCO expects that the office can shave power peak and reduce power consumption. Since the demonstration, the KEPCO has expanded SGS to 121 of its branch offices. However, the expansion is limited in KEPCO's internal branch offices. In other words, although it has been a few years since the first SGS was built, the smart grid industry is stagnant in Korea. The authors recognized an analysis was required to verify the performance of SGS and to propose a direction based on an analysis comparing current real operation data with early expectations.

\section{SGS Concept and Features}

The objectives of SGS are to optimize the usage of electricity and to reduce the electricity fee and consumption in a building, with various integrated technologies.

When renewable energy resources connected to both grid and ESS generated power, the power from renewable energy can be supplied to load directly or charged ESS. Also, the battery is charged from grid when the price is low and discharged when the price of electricity on the grid is high. This allows a building to save money and reduce power consumption. In this system, less energy production is required by fossil fuel generators during times of peak consumption. In consequence, SGS benefits the environment by reducing emissions of $\mathrm{CO}_{2}$. These effects are shown in Table 2 .

Table 2. Details of SGS

\begin{tabular}{|c|c|}
\hline Objective & $\begin{array}{l}\text { Reducing consumption and saving electricity fee by optimizing usage in a } \\
\text { building }\end{array}$ \\
\hline $\begin{array}{l}\text { Expected } \\
\text { Effects }\end{array}$ & $\begin{array}{l}\text { - Reduce } 5.0 \% \text { of electricity peak in a year } \\
\text { - Reduce } 9.6 \% \text { of power consumption for a year } \\
\text { - Save electricity fee } \\
\text { - Reduce } 5.0 \% \text { of CO2 for a year }\end{array}$ \\
\hline Features & $\begin{array}{l}\text { - Remote control of demand in a building } \\
\text { - Energy management system construction based on SG } \\
\text { - ICT convergence on intelligent energy management }\end{array}$ \\
\hline
\end{tabular}


The Guri SGS project consisted of two steps. The duration of the first step was from October, 2013 to February, 2014, and this step was for the installation of PV, ESS, a slow-charging type of EV charger, AMI, a smart distribution board, and building automation system (BAS) components. The goal of the first step was to optimize the building's energy consumption based on SG. The second step was for the addition of WT, control system of the heat, ventilation, and air conditioner (HVAC), and improving the Operation System. The duration of the second step was from December, 2014 to June, 2015.

Figure 1 is a diagram of SGS components. It shows the Operating System (OS), which is a software program that plays a key role in integrating other technologies. It can monitor and control each element remotely and maintain the power balance by communication between various components. In order to help small and mid-sized businesses, KEPCO adopted their products and integrated various systems as an ICT convergence. Each component will be specified in the Section 3.

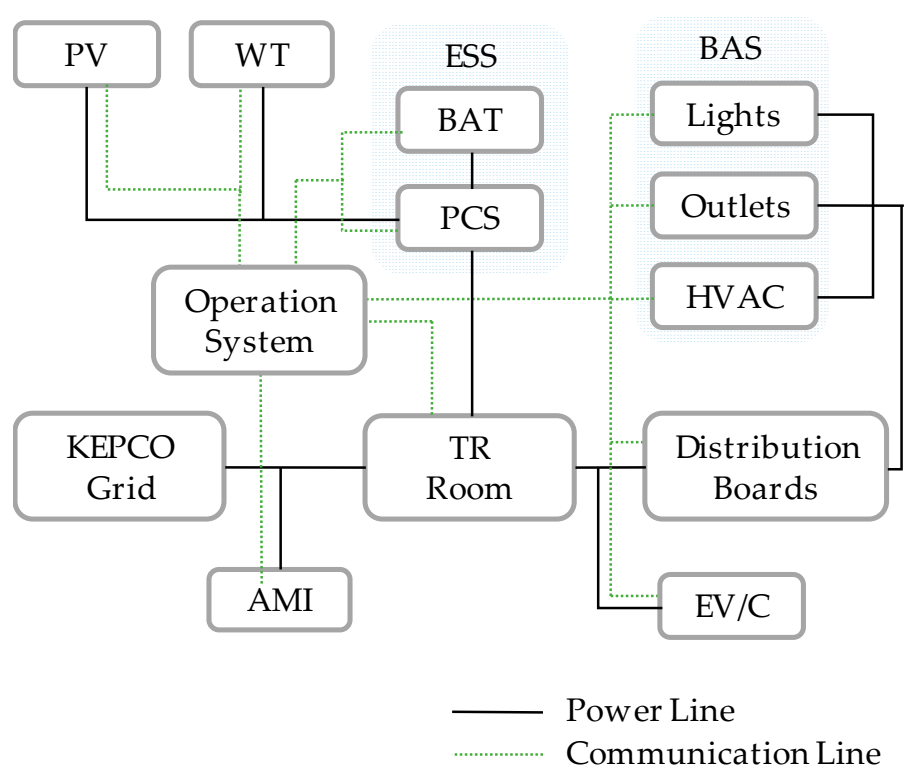

Figure 1. The main components of SGS

Table 3. Specification of PV System

\begin{tabular}{cl}
\hline Device & Monocrystalline Silicon \\
\hline Max Power & $250 \mathrm{Wp}(60$ Cells $)$ \\
\hline Max Voltage & $497.6 \mathrm{~V}(31.1 \mathrm{~V} \times 16)$ \\
\hline Efficiency & $15.7 \%$ \\
\hline Capacity & $20 \mathrm{kWp}(6$ by 14,84 modules, Dummy 4$)$ \\
\hline Connection & 16 series by 5 parallel \\
\hline
\end{tabular}

\section{Components Description}

\subsection{Photovoltaic}

The PV system was mounted at $30^{\circ}$ on the rooftop. The maximum power of each module is $250 \mathrm{~W}$, and the total capacity of the system is $20 \mathrm{kWp}$. The system is composed of 84 modules consisting of monocrystalline silicon cells, but 4 of them are dummies. The capacity was adopted at $5 \%$ of the contracted power $(400 \mathrm{~kW})$ of the Guri office. The PV system supplies the power the building on weekdays, and charges a battery on weekends. Table 3 is the specification of the PV system. 
100

101

102

103

104

105

106

107

108

109

110

111

112

113

114

115

116

The power from PV in summer season, from June to August, doesn't charge the battery but supply to building loads directly to reduce the peak and power consumption.

\subsection{Wind Turbine}

WT system was mounted on the rooftop from March, 2015. The PV system and the WT installed as Figure 2. This WT is not influenced by the direction of the wind since it is a vertical axis type wind turbines (VAWT) [7]. Also it doesn't make noise when the turbine rotates, and cut-in wind speed is light wind as $3 \mathrm{~m} / \mathrm{s}$. These features make the WT system easy to install on buildings, but the rated power is $1.2 \mathrm{~kW}$ at $15 \mathrm{~m} / \mathrm{s}$. Although this WT generates $53 \mathrm{kWh}$ for a year by Weibull performance calculations, the system is hard to contribute to reduce energy because the wind doesn't blow fast enough in urban area.
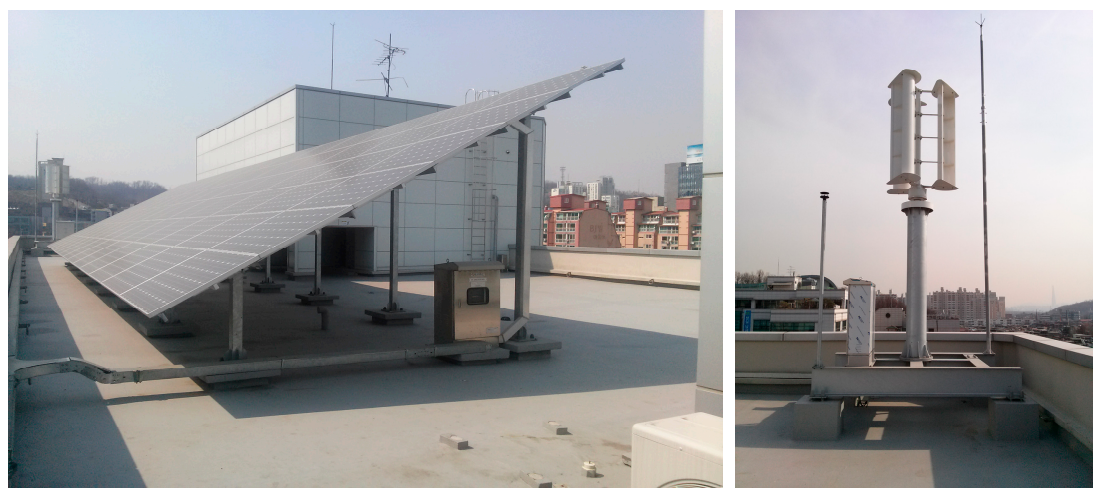

Figure 2. PV and WT system at Guri Office

Because this vertical type of WT has unstable output at certain wind speeds and low efficiency $[7,8]$, it has its own interconnected inverter to stabilize the output. Table 4 shows the features of WT, and Table 5 shows the details of this inverter.

Table 4. Performance Characteristics of WT

\begin{tabular}{ll}
\hline Type & Vertical Axis type \\
\hline Size & $1400 \times 1800 \mathrm{~mm}$ \\
\hline Rated Power & $1.2 \mathrm{~kW}$ at $15 \mathrm{~m} / \mathrm{s}$ \\
\hline Cut-in wind speed & $3 \mathrm{~m} / \mathrm{s}$ \\
\hline Extreme wind speed & $52.5 \mathrm{~m} / \mathrm{s}$ \\
\hline
\end{tabular}

Table 5. Specification of WT Inverter

\begin{tabular}{cll}
\hline \multirow{2}{*}{ Input } & Rated Voltage & $430 \mathrm{Vdc}$ \\
\cline { 2 - 3 } & Voltage Range & $60 \sim 600 \mathrm{Vdc}$ \\
\hline \multirow{3}{*}{ Output } & Max Capacity & $3 \mathrm{~kW}($ Single Phase $)$ \\
\cline { 2 - 3 } & Rated Voltage & $220 \mathrm{Vac}( \pm 10 \%)$ \\
\cline { 2 - 3 } & Rated Frequency & $60 \mathrm{~Hz}( \pm 0.5 \mathrm{~Hz})$ \\
\cline { 2 - 3 } & Efficiency & $98 \%$ \\
\cline { 2 - 3 } & Power Factor & $99 \%$ \\
\hline
\end{tabular}

\subsection{Energy Storage System}

ESS is composed of a battery and power conversion system (PCS). Figure 3 shows the battery and PCS installed on the rooftop. The ESS can be used for either on-grid status or off-grid status. The ESS has various effects: peak shaving, load leveling, providing constant voltage and constant frequency (CVCF), cost reduction, load compensation and so on [9]. In this paper, the authors focused 
122

123

124

125

126

127

128

129

130

131

132

133

134

135

136

137

138

139

140

141

142

143

144

on peak shaving, and load shifting. Regarding of the first function, the ESS charges power from renewable energy (RE) resources at the off-peak load time and discharges the power at the peak time. Regarding the second function, the ESS charges a battery with the power from the grid in the evening and discharges the battery in the afternoon. By cutting peak and shifting load, the electricity fee can be saved.

The PCS converts DC-to-AC and AC-to-DC. This means that it can function both a converter and an inverter. Usually, a PV system has its own inverter, but the PCS used in the SGS is a hybrid type. Figure 4 is the inner connection diagram of PCS. It makes it possible to charge or discharge the power of the PV, the WT, and the battery. The capacity of the PCS was determined to be $30 \mathrm{~kW}$, considered the capacity of the PV and the battery, in that the PV system has $20 \mathrm{~kW}$, and the battery was estimated to discharge at $10 \mathrm{~kW}$.
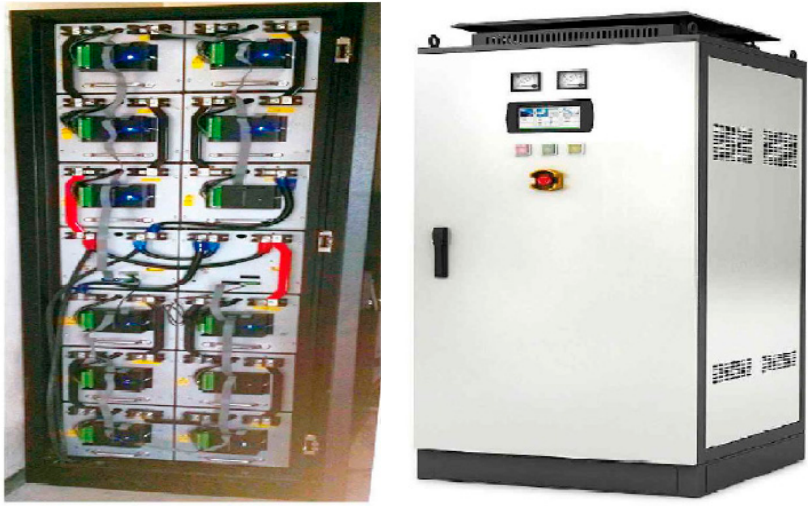

Figure 3. Battery (left) and PCS (right) on rooftop

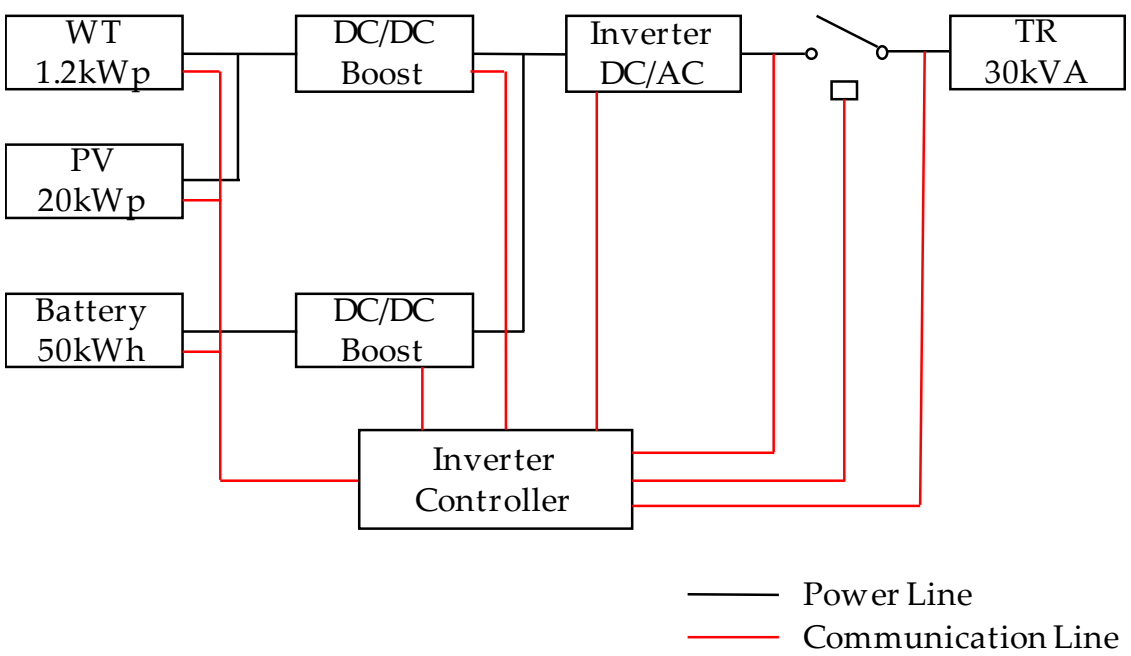

Figure 4. Battery (left) and PCS (right) on rooftop

A lithium iron phosphate ( $\mathrm{LiFePO} 4)$ battery was selected, and the size is $50 \mathrm{kWh}$. LiFePO4 has better thermal and chemical safety than other types of batteries [10]. The capacity was designed to discharge for five hours at $10 \mathrm{~kW}$. The life cycle is 4,000 cycles at $80 \%$ of depth of discharge. This means that the battery can be used 4,000 times if it charges-and-discharges power in the range of $20 \%$ to a full charge state. This range is established to prevent the battery from reaching a full discharge state. The specification of the ESS is in Table 6.

There are three discharge schedules that the operator adjusts, and those are as follows:

1. Uniform discharge: Discharges uniform amount of power from battery during peak and midload times continuously 
145

146

147

148

149

150

151

152

2. Continuous differential discharge: Continuously discharges during peak and mid-load times, but the amount is different during peak load time

3. Non-continuous differential discharge: Discharges non-continuously during peak and mid-load times, and the amount is different during peak-load time

In summary, the ESS charges the batteries at the off-peak load time and discharges them during the peak and mid load times on weekdays. It is expected that a customer can reduce power peak by $5 \%$ with these schedules.

Table 6. Specification of ESS

\begin{tabular}{ccc}
\hline & Capacity & 30kW/30kVA, 60Hz \\
\cline { 2 - 3 } PCS & Control System & PWM converter \\
\cline { 2 - 3 } & Max Efficiency & $90 \%$ \\
\cline { 2 - 3 } & Power Factor & Over 95\% \\
\cline { 2 - 3 } & Max Input Voltage & 800Vdc from Battery \\
\cline { 2 - 3 } & Output & $450 \sim 850 \mathrm{Vdc}$ from PV \\
\cline { 2 - 3 } BAT & Capacity & $45 \mathrm{~A}$ \\
\cline { 2 - 3 } & Charge-Discharge Efficiency $(25 \mathrm{kWh} \times 2)$ \\
\cline { 2 - 3 } & Cell Voltage & 95\% \\
\cline { 2 - 3 } & Rack Voltage & $422.4 \mathrm{~V}(11 \mathrm{~V}, 20 \mathrm{Ah}$ \\
\cline { 2 - 3 } & Nominal Voltage & $422.4 \mathrm{~V}(369.6 \mathrm{~V} \sim 468.6 \mathrm{~V})$ \\
\hline
\end{tabular}

\section{3}

154

155

156

157

158

159

160

\subsection{Advanced Metering Infrastructure}

An AMI installed in a transformer room of the SGS measures the amount of power supplied from the grid and checks the qualities of voltage, current, and frequency. A general electricity meter monitors power quality every 15 minutes, but the AMI exports the data in real-time. The exported data are used to calculate the real-time electricity fee and analyze the operation status. This AMI is connected in series a connection to current, and in a parallel connection to voltage. Figure 5 shows the picture and the connection of the AMI, and Table 7 is the detail specification of the AMI.

Table 7. Specification of AMI

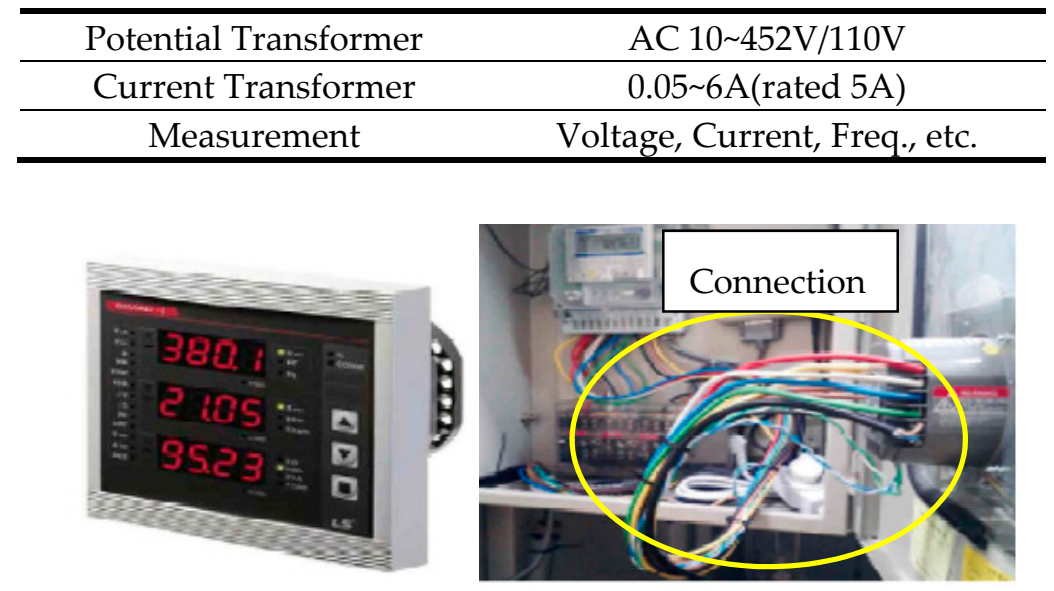

Figure 5. Pictures of AMI and connection line

\subsection{Electric Vehicle Chargers}

Outside of the building, there are 6 EV chargers. Four of them are a slow-charging type, and the others are a fast-charging type. The slow-charging type has an AC type of connector and charges the $\mathrm{EV}$ at $7 \sim 8 \mathrm{~kW}$ through a single phase of $220 \mathrm{Vac}$, and it takes about 5 to 6 hours to reach a full charge. 
The fast-charging type has 3 kinds of sockets: CHAdeMO, Combo, and 3-phase AC type. CHAdeMO and Combo supply power in DC. The fast-charging type chargers supply power at $50 \mathrm{~kW}$ by $380 \sim 450 \mathrm{Vdc}$ or $380 \mathrm{Vac}$. However, because of the inconvenience caused by different types of connectors, there is a trial to standardize the shapes of connectors currently. In fact, the EV chargers are considered as loads, but potentially, they can be bridges to implement the vehicle to grid (V2G) [11].

\subsection{Building Automation System}

For an automation system in a building, CTs are installed in each distribution board to measure the power quality and the consumed energy by the hour and by the device. Also, smart outlets and light switches were newly installed, and these can be controlled remotely by the Operation System.

The outlets can cut off standby power. Their rated allowable current is 16A, and their overload current is 20A. For the smart lighting, gateways were installed to transmit control signals to the lighting from the OS.

The other controllable system of the BAS is heating, ventilation, and air conditioning (HVAC). The OS adjusts the air quality by controlling the frequency of the variable frequency drives (VFDs) to reduce energy consumption.

To measure power consumption of each device, current transformers (CT) are installed in distribution panels. These CTs are solid-ring and split-core types, and they communicate with a multi-channel power meter by Modbus.

\subsection{SGS Operation Sytstem}

In the SGS, the Operation System plays a role as energy management system (EMS). This is a software program that can integrate the other components. These are connected in communication lines, and the data of the devices are gathered into the operation system. This means that the system can monitor the power consumption of all components in the building in real-time. Moreover, it has a human machine interface (HMI) that shows the details of the components. Figure 6 (a) shows that the OS has three categories: system configuration, management, and statistics. This is the main page of the OS, and from this page, an operator can select any other page.

The first page, system configuration, shows the real-time power flow. In this section, users can check the status of components and monitor the general data, including electricity fee information, supplied power from each source, and power consumption of the building. This helps users to understand the power flow, and Figure 6 (b) shows it. On this page, the operator reviews the overall function of the system. Figure 6 (c) includes the information on the communication status of each device.

The OS gathers various data from the devices in the communication by Modbus and Zigbee. Based on these data, the OS is able to turn each light switch and outlet on and off and to manage the PCS and BAS in the management section. Figure $6(\mathrm{~d})$ shows monitoring of the power consumption on each floor. Figure 6 (e) and (f) are control pages for lights and outlets. Figure 6 (g) and (h) show VFDs and HVAC.

Specifically, the operator can set schedules for these devices. Regarding the PCS, the OS controls the charge-discharge operation mode as shown in Table 8. The output of the WT is too small to contribute to the modes.

The statistics section comprises an overall analysis, DER analysis, and load forecasting. Overall analysis is for supplied power and peak per day, month, and year. Figure 6 (i) is the page of the monthly analysis of supply/demand. The DER analysis shows the PV generation and the amount of battery discharge. One of the main functions of the OS is to forecast the demand of electricity by its own algorithm. Through this analysis, the OS controls the devices and power flow, and decides to charge or discharge the battery. 


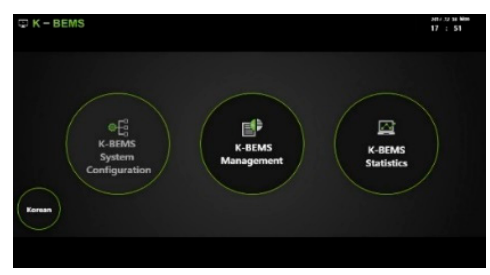

(a)

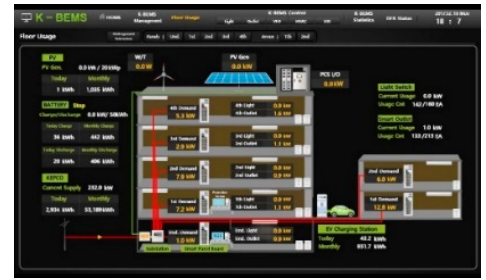

(d)

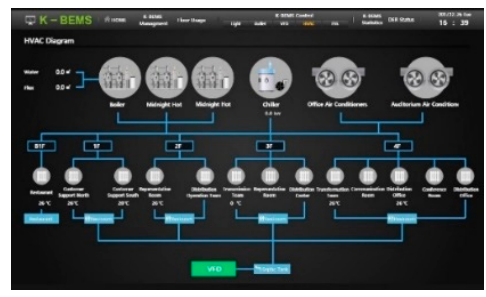

(g)

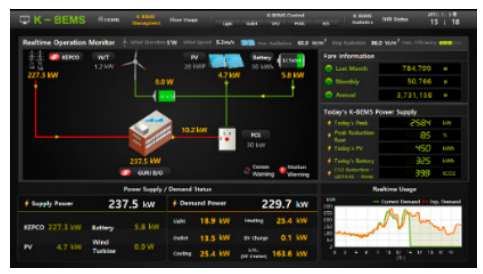

(b)

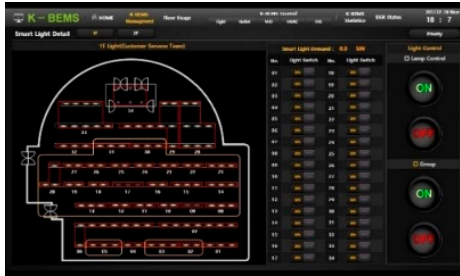

(e)

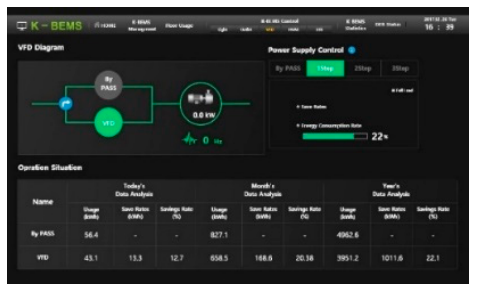

(h)

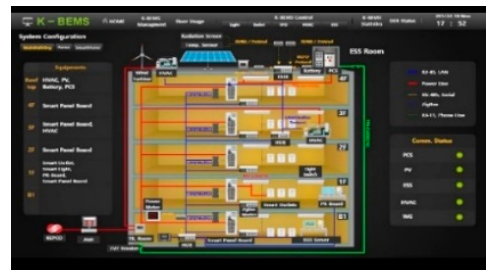

(c)

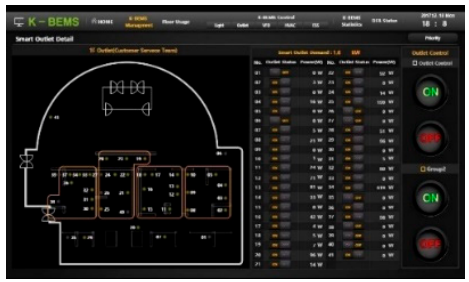

(f)

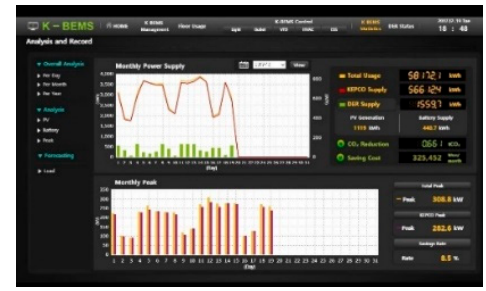

(i)

Figure 6. Operation System displays

Table 8. Operation Modes of PCS

\begin{tabular}{ccl}
\hline Status & Mode & \multicolumn{1}{c}{ Description } \\
\hline \multirow{2}{*}{ Charge } & Full charge & Full Charge by PV + Grid \\
\cline { 2 - 3 } & Only PV Charge & Charge by only PV \\
\cline { 2 - 3 } Discharge & Full discharge & Supply power to loads by PV + BAT \\
\cline { 2 - 3 } & Fix PCS output & $\begin{array}{l}\bullet \text { Fix PCS output } \\
\text { •BAT output varies with PV output }\end{array}$ \\
\cline { 2 - 3 } & Fix BAT output & $\begin{array}{l}\bullet \text { Fix BAT output } \\
\bullet \text { PCS output varies with PV output }\end{array}$ \\
\cline { 2 - 3 } Concurrent & Only PV discharge & Supply power to loads by only PV \\
\cline { 2 - 3 } & Fix BAT charge & $\begin{array}{l}\bullet \text { Some of PV output charges BAT } \\
\bullet \text { Other supplies to loads }\end{array}$ \\
\cline { 2 - 3 } & Fix PCS output & $\begin{array}{l}\bullet \text { Some of PV output supplies to loads } \\
\bullet\end{array}$ \\
\hline
\end{tabular}

\section{Performance Evaluation}

To evaluate the performance of Smart Grid Station, the authors analyzed the reduction of peak and consumption, as well as, economy by comparison with the early targets.

The performance analysis is based on Smart Grid Station operation algorithm shown in Figure 7. Following the algorithm, power from KEPCO grid charges the battery at off-peak load times, such as night time or on weekends. Also, if the generation of the PV and WT is over the power demand, the extra power goes to charge the battery. On the other hand, the grid power, renewable energy sources, and battery supply to loads, including the EV/C, outlets, lights, and HVAC, at the peak-load time and mid-load time. The Operation System gathers and monitors these generating, supplying, and demanding data. 


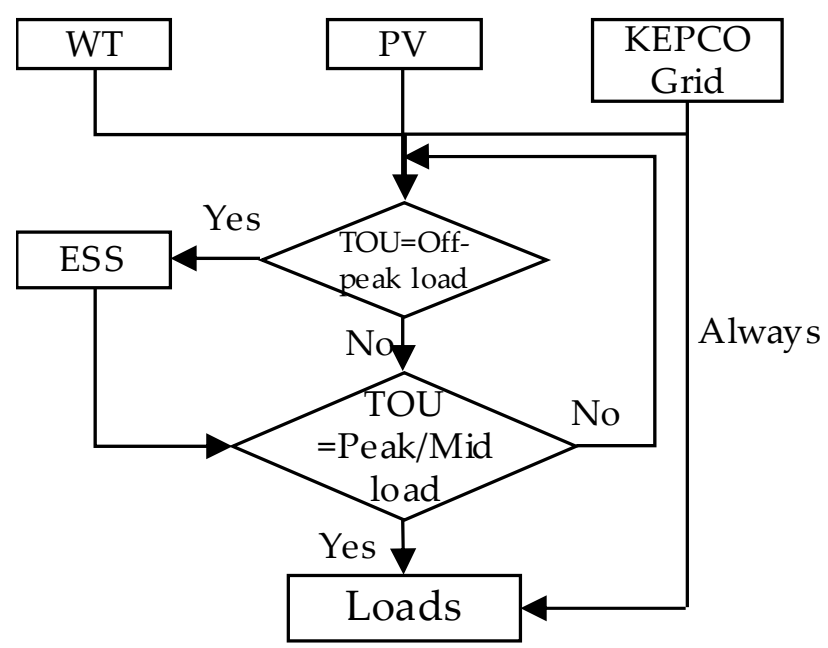

Figure 7. Smart grid Station Operation Algorithm

In the SGS, the peak power and consumption are reduced due to the DER. This makes it difficult

to directly compare the decreased value with the unreduced value that could have been measured if not for the reduction. For this reason, the authors tried to compare the reduced peak and consumption with the values from 2014; however, new equipment and appliances were installed in the supervisory control and data acquisition (SCADA) room and the temporary office of the city of Namyangju in the Guri branch office, and we considered these changes in increment. Table 9 shows the details of increment in the building, and the authors assume usage time of the devices as in Table 10.

As the equipment for the SCADA room is ICT equipment, it is always used, even on weekends. Because the air conditioning system is an ice storage system, it does not contribute to a rise in the peak. Printers and cooling fans were considered to be unused during peak time to save energy.

Table 9. Newly Installed Equipment and Appliances

\begin{tabular}{|c|c|c|c|c|c|c|c|c|}
\hline & \multirow{2}{*}{$\begin{array}{l}\text { Installation } \\
\text { Date }\end{array}$} & \multirow[b]{2}{*}{ Items } & \multirow{2}{*}{$\begin{array}{c}\text { Capacity } \\
(\mathrm{kW})\end{array}$} & \multicolumn{2}{|c|}{ Using hours } & \multicolumn{3}{|c|}{ Consumption } \\
\hline & & & & $\begin{array}{c}\text { Per a } \\
\text { weekday }\end{array}$ & $\begin{array}{c}\text { Per a } \\
\text { weekend }\end{array}$ & $\begin{array}{c}\text { Aug } \\
(\mathrm{kWh})\end{array}$ & $\begin{array}{c}\text { Sept } \\
(\mathrm{kWh})\end{array}$ & $\begin{array}{l}\text { Total } \\
(\mathrm{kWh}) \\
\end{array}$ \\
\hline \multirow{5}{*}{ SCADA } & \multirow{5}{*}{$\begin{array}{l}2014 \\
10.30\end{array}$} & Media Rack & 0.72 & \multirow{5}{*}{24} & \multirow{5}{*}{24} & \multirow{5}{*}{$10,460.6$} & \multirow{5}{*}{$10,123.2$} & \multirow{5}{*}{$20,583.8$} \\
\hline & & Audio Rack & 0.5 & & & & & \\
\hline & & 6 DLP Cube & 1.32 & & & & & \\
\hline & & 4 LED TVs & 0.52 & & & & & \\
\hline & & Humidifier & 11 & & & & & \\
\hline \multirow{12}{*}{$\begin{array}{l}\text { Temp. } \\
\text { office }\end{array}$} & \multirow{9}{*}{$\begin{array}{l}2015 \\
03.24\end{array}$} & Lights & 1.8 & 10 & - & 378 & 360 & 738 \\
\hline & & $\begin{array}{c}13 \text { Computers } \\
(400 \mathrm{~W})\end{array}$ & 5.2 & 10 & - & 1,092 & 1,040 & 2,132 \\
\hline & & $\begin{array}{c}13 \text { Computers } \\
(300 \mathrm{~W})\end{array}$ & 3.9 & 10 & - & 819 & 780 & 1,599 \\
\hline & & $\begin{array}{c}21 \text { Monitors } \\
(170 \mathrm{~W})\end{array}$ & 3.7 & 10 & - & 777 & 740 & 1,517 \\
\hline & & $\begin{array}{c}\text { Hot\&Cold } \\
\text { dispenser }\end{array}$ & 0.85 & 24 & 24 & 632.4 & 612 & $1,244.4$ \\
\hline & & $\begin{array}{l}\text { Air Handling } \\
\text { Unit }\end{array}$ & 12.5 & 10 & - & 2,625 & 2,500 & 5,125 \\
\hline & & 10 Cooling Fans & 0.3 & 6 & - & 37.8 & 36 & 73.8 \\
\hline & & $\begin{array}{c}4 \text { Printers } \\
(700 \mathrm{~W}) \\
\end{array}$ & 2.8 & 1 & - & 58.8 & 56 & 114.8 \\
\hline & & $\begin{array}{c}\text { Ice Storage AC } \\
\text { Sys. }\end{array}$ & 15 & 10 & - & 3,150 & 3,000 & 6150 \\
\hline & \multicolumn{4}{|c|}{ Total Consumption(kWh) } & & $20,030.6$ & $19,247.2$ & $39,277.8$ \\
\hline & \multicolumn{4}{|c|}{ The number of weekdays in each month } & & 21 days & 20 days & \\
\hline & \multicolumn{4}{|c|}{ The number of weekends in each month } & & 10 days & 10 days & \\
\hline
\end{tabular}


Table 10. Details of Usage Time

\begin{tabular}{ccccc}
\hline & \multicolumn{3}{c}{ Usage hours } & \multirow{2}{*}{ Note } \\
\cline { 2 - 4 } & Off-peak load & Mid load & Peak load & \\
\hline SCADA & 6 & 8 & 10 & All days \\
\hline Office Facilities $^{1}$ & 6 & 3.5 & 0.5 & $\begin{array}{c}\text { 08:30 18:30 } \\
\text { on Weekdays }\end{array}$ \\
\hline $\begin{array}{c}\text { Hot\&Cold } \\
\text { Dispenser }\end{array}$ & 6 & 8 & 10 & All days \\
\hline $\begin{array}{c}\text { Ice Storage } \\
\text { AC System }\end{array}$ & - & - & 10 & Weekdays \\
\hline Printers & 1 & - & - & Weekdays \\
\hline Cooling fans & 5 & 1 & - & Weekdays \\
\hline
\end{tabular}

${ }^{1}$ Lights, computers, monitors, and air handling unit

\subsection{Peak Shaving}

For a commercial building, once a peak power is measured, the peak is adopted for the electricity fee in the year. The maximum peak occurred in the summer. Thus, the authors compared the peak that occurred in August and September of 2014 with the peak in same months of 2015 as Table 11.

Table 11. Comparison of Peak

\begin{tabular}{cccc}
\hline & Day Peak [kW] & Evening Peak [kW] & Max Peak [kW] \\
\hline '15.08 & 285.12 & 294.24 & \multirow{2}{*}{294.24} \\
\hline '15.09 & 255.84 & 213.12 & \\
\hline '14.08 & 271.08 & 259.56 & \multirow{2}{*}{271.08} \\
\hline '14.09 & 255.96 & 237.24 & \\
\hline
\end{tabular}

Peak shaving ratio (PSR) is a ratio between the maximum peak in 2015 and the maximum peak in 2014 .

$$
\begin{gathered}
\text { Peak }_{\text {add }}=42.01 \mathrm{~kW} \times 0.9 \cong 37.8 \mathrm{~kW} \\
\operatorname{PSR}(\%)=\left|\frac{P e a k_{\text {max }}^{2015}-P_{e a k_{a d d}}}{\text { Peak }_{\text {max }}^{2014}} \times 100-100\right| \\
\operatorname{PSR}(\%)=\left|\frac{294.24-37.8}{271.08} \times 100-100\right|=5.40 \%
\end{gathered}
$$

In (1), $42.01 \mathrm{~kW}$ is a sum of the capacity of all equipment except cooling fans, printers, and the ice storage AC system in Table 9. The value of added equipment capacity defined in (1) should be subtracted from max peak in 2015. This value is an estimate of the capacity multiplied by the power factor (0.9). In (1) and (2), the result of the PSR is $5.40 \%$. This means that the early target of $5 \%$ reduction in peak has been surpassed.

\subsection{Consumption Reduction}

The second effect of the SGS is the reduction of power consumption. The data used to calculate peak reduction in Section 4.1 was also used in this section.

The consumption is separated into three time periods: off-peak load, mid load, and peak load, as shown in Table 12. The added power consumption is subtracted from the total consumption in 2015. The consumption reduction ratio (CRR) is calculated in (5). In (4) and (5), the result is approximately $11.26 \%$. This indicates that the initial target is also achieved. 
Table 12. Monthly Consumption

\begin{tabular}{ccccc}
\hline & \multicolumn{4}{c}{ Consumption (kWh) } \\
\cline { 2 - 4 } & Off-peak load & Mid load & Peak load & Total \\
\hline '15.08 & 24,299 & 20,703 & 19,128 & \multirow{2}{*}{123,807} \\
\hline '15.09 & 27,478 & 17,619 & 14,580 & \\
\hline '14.08 & 7,844 & 21,322 & 18,891 & \multirow{2}{*}{99,686} \\
\hline '14.09 & 17,695 & 19,343 & 14,591 & \\
\hline
\end{tabular}

265

$$
\begin{array}{r}
\text { Con }_{\text {add }}=39,277.8 \mathrm{kWh} \times 0.9 \cong 35,350 \mathrm{kWh} \\
\operatorname{CRR}(\%)=\left|\frac{\text { Con }_{\text {max }}^{2015}-\text { Con }_{\text {add }}}{\operatorname{Con}_{\text {max }}^{2014}} \times 100-100\right| \\
\operatorname{CRR}(\%)=\left|\frac{123,807-35,350}{99,686} \times 100-100\right|=11.26
\end{array}
$$

\subsection{Saved Electricity Fee}

There are two kinds of electric rates: demand charge and energy charge. Demand charge is for the peak measured, and energy charge is different in each season. Time periods are divided into

\begin{tabular}{|c|c|c|c|}
\hline Load Time & Summer & Spring/Fall & Winter \\
\hline \multirow{2}{*}{ Off-peak load time } & \multicolumn{2}{|c|}{ 23:00 09:00 } & \multirow{2}{*}{ 23:00 09:00 } \\
\hline & & \\
\hline \multirow{3}{*}{$\begin{array}{l}\text { Mid load } \\
\text { Time }\end{array}$} & \multicolumn{2}{|c|}{ 09:00 10:00 } & 09:00 10:00 \\
\hline & \multicolumn{2}{|c|}{$12: 00 \sim 13: 00$} & $12: 00 \sim 17: 00$ \\
\hline & \multicolumn{2}{|c|}{ 17:00 23:00 } & 20:00 22:00 \\
\hline \multirow{3}{*}{$\begin{array}{l}\text { Peak load } \\
\text { time }\end{array}$} & \multirow{3}{*}{\multicolumn{2}{|c|}{$\begin{array}{l}10: 00 \sim 12: 00 \\
13: 00 \sim 17: 00\end{array}$}} & 10:00 12:00 \\
\hline & & & 17:00 20:00 \\
\hline & & & 22:00 23:00 \\
\hline
\end{tabular}
summer, spring/fall, and winter. Exact time periods are shown in Table 13.

Table 13. Segmentation by Season and Time [12]

Electric rate refers to each type of customers. General Service rate which is classified in General Service (A) I, General Service (A) II and General Service (B) is for building customers. These rates are subdivided into High-Voltage A for $3.3 \mathrm{kV}$ to $66 \mathrm{kV}$ and High-Voltage B ranged over $154 \mathrm{kV}$. Besides, customers can choose option I, option II or option III depending on the customers' electricity using time for a month. The High-Voltage A option II of General Service (B) is for the customers who use electricity for 200 500 hours per month, and whose contract demand of $300 \mathrm{~kW}$ or more. The details

\begin{tabular}{|c|c|c|c|c|}
\hline \multicolumn{2}{|c|}{ Demand charge } & \multicolumn{3}{|c|}{ 8,320 won/kW } \\
\hline \multirow{4}{*}{$\begin{array}{l}\text { Energy charge } \\
\text { (won/kWh) }\end{array}$} & Time period & Off-peak load & Mid Load & Peak Load \\
\hline & $\begin{array}{c}\text { Summer } \\
\text { (Jun.1 Aug.31) }\end{array}$ & 56.1 & 109.0 & 191.1 \\
\hline & $\begin{array}{c}\text { Spring/Fall } \\
\text { (Mar.1 May.31/ } \\
\text { Sep.1 Oct.31) }\end{array}$ & 56.1 & 78.6 & 109.3 \\
\hline & $\begin{array}{c}\text { Winter } \\
\text { (Nov.1 Feb.28) }\end{array}$ & 63.1 & 109.2 & 166.7 \\
\hline
\end{tabular}
are shown on Table 14.

Table 14. Electric Rates Table for High-Voltage A Option II of General Service (B) [12] 
283

284

285

286

287

288

289

290

291

292

Each of total power consumption and electricity fee in 2014 and 2015 is on Table 15. To calculate the Saved Fee Ratio (SFR), the added fees were also considered. These fees are on Table 16 and Table 17. By (7), the sum of added fees is $4,127,892$ won, and the FRR is calculated as $10.15 \%$.

$$
\begin{gathered}
F e_{\text {add }}=\text { Charge }_{\text {demand }}+\text { Charge }_{\text {energy }} \\
\text { SFR }(\%)=\left|\frac{F e e^{2015}-F e e_{\text {add }}}{F e e^{2014}} \times 100-100\right| \\
\operatorname{SFR}(\%)=\left|\frac{15,924,000-4,127,892}{13,128,000} \times 100-100\right|=10.15 \%
\end{gathered}
$$

Although there was not an early target for fee reduction, the analysis of electricity fees is enough to prove the effects of the Smart Grid Station.

Table 15. Total Electricity Fee in 2014 and 2015

\begin{tabular}{cccc}
\hline Date & Consumption (kWh) & Fee (won) & \multirow{2}{*}{ Total (won) } \\
\hline '15.08 & 64,130 & $8,659,000$ & \multirow{2}{*}{$15,924,000$} \\
\hline '15.09 & 59,677 & $7,265,000$ & \\
\hline '14.08 & 48,057 & $6,424,000$ & \multirow{2}{*}{$13,128,000$} \\
\hline '14.09 & 51,629 & $6,704,000$ & \\
\hline
\end{tabular}

Table 16. Demand Charge for Added Loads in 2015

\begin{tabular}{cccc}
\hline Month & Max Peak & Demand Charge & Charged Fee \\
\hline Aug & $37.8 \mathrm{~kW}$ & 8,320 won $/ \mathrm{kW}$ & $314,496 \mathrm{won}$ \\
\hline Sept & $37.8 \mathrm{~kW}$ & 8,320 won $/ \mathrm{kW}$ & $314,496 \mathrm{won}$ \\
\hline
\end{tabular}

Table 17. Energy Charge for Added Loads in 2015

\begin{tabular}{cccc}
\hline & $\mathbf{2 0 1 5}$ & Consumption (kWh) & Fee $^{\mathbf{1}}$ (won) \\
\hline \multirow{3}{*}{ Aug } & Off-peak Load & 7744 & 304,041 \\
\cline { 2 - 4 } & Mid load & 5481.4 & 387,755 \\
\cline { 2 - 4 } & Peak load & 6021.0 & 761,778 \\
\cline { 2 - 4 } & Total & 19247.2 & $1,453,574$ \\
\hline \multirow{3}{*}{ Sept } & Off-peak Load & 8056.7 & 406,783 \\
\cline { 2 - 4 } & Mid load & 5695.8 & 558,758 \\
\cline { 2 - 4 } & Peak load & 6278.2 & $1,079,785$ \\
\cline { 2 - 4 } & Total & 20030.7 & $2,045,326$ \\
\hline
\end{tabular}

${ }^{1} 0.9$ of power factor is applied in the Fee, and decimal point is rounded up

\section{Economic Analysis of Smart Grid Station}

In Section 5, we studied the contribution with regard to the economic aspects, especially the contributions of PV generation, EV, and energy time shifting by the ESS.

\subsection{Saved Electricity Fee by PV generation}

During August and September of 2015, PV generation was 2,961.5kWh in August and $2,326.1 \mathrm{kWh}$ in September. The total saved fee is the sum of saved demand charge (SDC) and saved energy charge (SEC), contributed by PV system.

$$
\begin{aligned}
& \mathrm{SDC}=P_{P C S}^{M a x}(\mathrm{~kW}) \times \text { Charge }_{\text {demand }} \\
& \mathrm{SEC}=W_{D E R}(\mathrm{kWh}) \times \text { Charge }_{\text {energy }}
\end{aligned}
$$

It is difficult to know when the PV system generated power and how much the system generated. For this reason, the authors assumed the PV supplied power to loads at peak-load time 
305

306

307

308

309

310

311

312

313

314

315

316

317

318

319

320

321

322

323

and mid-load time in ratio of 8 to 2. Using the information above and (11), the SDC and the SEC in August were found to be as follows:

$$
\mathrm{SDC}=30 \mathrm{~kW} \times 8,320 \mathrm{won} / \mathrm{kW}=249,600 \mathrm{won}
$$

$$
S E C_{A u g}=2,961.5 \mathrm{kWh} \times(191.1 \mathrm{won} / \mathrm{kWh} \times 0.8+109.0 \mathrm{won} / \mathrm{kWh} \times 0.2)=517,374 \mathrm{won}
$$
from September are as follows:

$$
S E C_{\text {Sept }}=2,326.1 \mathrm{kWh} \times(109.3 \mathrm{won} / \mathrm{kWh} \times 0.8+78.6 \mathrm{won} / \mathrm{kWh} \times 0.2)=239,960 \mathrm{won}
$$

In conclusion, the total saved fee is $1,256,534$ won.

\subsection{Running Cost Reduction by EV}

There was one electric vehicle in 2015, and the running data is on Table 18. In August and September, the EV ran in $470 \mathrm{~km}$ and $345 \mathrm{~km}$, respectively. We assumed the fuel efficiency of a gasoline-powered car is $10 \mathrm{~km} / \mathrm{L}$. Referring to the data, we compared the running cost (RC) of the EV with that of a gasoline-powered vehicle.

Table 18. Running Data of EV in 2015

\begin{tabular}{ccccc}
\hline Month & Mileage & $\begin{array}{c}\text { EV charge Amount } \\
\text { (kWh) }\end{array}$ & $\begin{array}{c}\text { Price of } \mathbf{1 k W h} \\
\text { (won/kWh) }\end{array}$ & $\begin{array}{c}\text { Price of Gasoline }{ }^{\mathbf{1}} \\
\text { (won/L) }\end{array}$ \\
\hline Aug & $470 \mathrm{~km}$ & 105.8 & 109 & 1,560 \\
\hline Sept & $345 \mathrm{~km}$ & 68.4 & 78.6 & 1,590 \\
\hline \multicolumn{1}{l}{ The price of gasoline is the average value of the month }
\end{tabular}

$$
\begin{array}{r}
R C_{\text {Gas }}=\frac{\text { mileage }(\mathrm{kW})}{\mathrm{km} / \mathrm{L}} \times \text { Price }_{\text {Gasoline }} \\
R C_{E V}=W_{E \text { charge }} \times \text { Price }_{W}
\end{array}
$$

By substituting figures, the results are as follows:

$$
R C_{\text {Gas }}^{\text {Aug }}=\frac{470 \mathrm{~kW}}{10 \mathrm{~km} / \mathrm{L}} \times 1,560 \mathrm{won} / L=73,320 \text { won }
$$

$$
R C_{E V}^{A u g}=105.8 \mathrm{kWh} \times 109 \text { won } / \mathrm{kWh} \cong 11,533 \text { won }
$$

$$
R C_{\text {Gas }}^{\text {Sept }}=\frac{345 \mathrm{~kW}}{10 \mathrm{~km} / \mathrm{L}} \times 1,590 \mathrm{won} / L=54,855 \text { won }
$$

$$
R C_{E V}^{\text {Sept }}=68.4 \mathrm{kWh} \times 78.6 \mathrm{won} / \mathrm{kWh} \cong 5,377 \text { won }
$$

Using (17) and (18), 61,787 won were saved, which means about $84.3 \%$ of the running cost was saved by the EV in August. These equations also show that 49,478 won, about $90.2 \%$ of the cost, were saved in September. Although the actual amount saved is small, this shows that the EV is much more effective than a gasoline-powered vehicle.

\subsection{Saved Fee by ESS Scheduling}

A customer charges the battery of the ESS at night, when the price of electricity is low, and discharges the power at the peak load time or mid load time when the price is highs. However, the power from PV system doesn't charge the battery but supplies power to the building load directly in the summer to maximize the efficiency. In August, $758.9 \mathrm{kWh}$ was charged to the battery, and same amount was discharged. In September, $541.1 \mathrm{kWh}$ was charged and discharged. Also we adapted the same assumption stated in Section 5.1. Equation (21) is a formula to calculate the fee reduction (FR). Time of use (TOU) applied in this equation is an electricity fee policy that varies with seasons and times, as shown in Table 14.

$$
\mathrm{FR}=\left(W_{\text {discharge }} \times \mathrm{TOU}\right)-\left(W_{\text {charge }} \times f e e_{\text {off-peak }}\right)
$$


By substituting figures, the results are as follows:

$$
\begin{gathered}
F R_{\text {Aug }}=[758.9 \times(191.1 \times 0.8+109.0 \times 0.2)]-(758.9 \times 56.1) \cong 89,991 \text { won } \\
F R_{\text {Sept }}=[541.1 \times(109.3 \times 0.8+78.6 \times 0.2)]-(541.1 \times 56.1) \cong 26,465 \text { won }
\end{gathered}
$$

As the calculations show, 116,456 won was saved for two months. By load shifting, the cost of electricity was greatly reduced.

\section{Discussion}

The authors verified the performance and economic feasibility of the Smart Grid Station to propose a future strategy. The performance was evaluated with regard to three aspects: peak shaving, reduction of power consumption, and electricity fee saving. Also, the economic efficiency was feasible in terms of electricity fee and running cost of the EV. Measured values in 2015 are revised for objective comparisons with values in 2014 before the SGS was built.

As described in Sections 4 and 5, the effectiveness of the SGS has been proven. However, smart grid technology is led by KEPCO in Korea, and the expansion of the technology is otherwise stagnant. This is because public institutions are leading the SG industry without supporting price policies for devices, and the private sector dose not participate in the industries actively, despite the effectiveness of the SGS. To support the expansion of SG, the convenience, safety and efficiency of SGS should be improved for customers. Also through the upgrade of the EMS, the system can integrate and control more various devices and technologies. To fulfill these requirements, the government needs to establish supporting policies.

\section{Conclusions}

As climate has changed, many countries have tried to prevent negative environmental impact. One of the efforts made toward this end is the smart grid. In Korea, KEPCO is evolving the SG technologies and expanding them to most of its branch offices. In this paper, the authors studied the first demonstration of SGS in the Guri branch office to prove the effectiveness.

The early main targets were a $5 \%$ reduction of peak, a $9.6 \%$ reduction of consumption, and savings in electricity fees. To evaluate the performance objectively, we compared the factors in 2015 with the values in 2014, while considering the increased loads in 2015. These operational analyses confirmed that peak was reduced by $5.40 \%$, consumption by $11.26 \%$, and fees by $10.15 \%$. Also the economic analysis shows that the SGS is an effective solution for a building. Considering its effectiveness, we suggest the expansion of the SGS to more customers. By expanding it to the private sector, smart grid will contribute to the building of a smart city, which is a city-sized of energy solution. As a next step, the authors will study SG policies and the improvements.

379 Conflicts of Interest: The authors declare no conflict of interest.

\section{$380 \quad$ References}

381 1. ADOPTION OF THE PARIS AGREEMENT, UNFCCC, Paris, France, 2015

382 2. Enhanced Actions on Climate Change, Department of Climate Change, national Development \& Reform

Author Contributions: Jaehong Whang designed and wrote the paper. Woohyun Hwang supported and helped to collect the data. Yeuntae Yoo and Gilsoo Jang conducted the review. Gilsoo Jang contributed to the modification. All the authors have read and approved the final manuscript.

Acknowledgments: This work was supported by Korea Electric Power Corporation (R17XA05-4) and under the framework of international cooperation program managed by National Research Foundation of Korea (No. 2017K1A4A3013579).

Commission of China, Beijing, China, 2015.

3. SUBMISSION BY LATVIA AND THE EUROPEAN COMMISSION ON BEHALF OF THE EUROPEAN UNION AND ITS MEMBER STATES, Latvian Presidency of the Council of the European Union, 2015.

4. Submission of Japan's Intended Nationally Determined Contribution, Japan, 2015.

5. Submission by the Republic of Korea Intended Nationally Determined Contribution, Korea, 2015. 
388 6. S. Borlase, "Smart Grid Technologies," in Smart Grids Infrastructure, Technology, and Solutions; CRC Press: Boca Raton, FL, USA, 2015; pp.79-125, 978-1-4398-2905-9

7. M. Ragheb, “Vertical Axis Wind Turbines," University of Illinois at Urbana-Champaign, 2011.

8. J. Fadil, Soedibyo, and M. Ashari, "Performance Comparison of Vertical Axis and Horizontal Axis Wind Turbines To Get Optimum Power Output," 2017 15 th International Conference on Quality in Research: International Symposium on Electrical and Computer Engineering, 2017, pp. 429-433.

9. A. Mohd, E. Ortjohann, A. Schmelter, N. Hamsic, and D. Morton, "Challenges in Integrating Distributed Energy Storage Systems into Future Smart Grid," in Proc. IEEE ISIE, Cambridge, U.K., Jun. 30-Jul. 2, 2008, pp.1627-1632.

10. E. Alegria, T. Brown, E. Minear, and R. H. Laseter, “CERTS Migcrogrid Demonstration With Large-Scale Energy Storage and Renewable Generation," IEEE Trans. Smart Grid, vol.5, no.2, pp. 937-943, Mar. 2014.

11. K. M. Tan, V. K. Ramachandaramurthy, and J. Y. Yong, "Integration of electric vehicles in smart grid: A review on vehicle to grid technologies and optimization techniques," Renewable and Sustainable Energy Reviews, vol.53, pp.720-732, Jan. 2016.

12. KEPCO General Service Electricity rate table. Available online: http://cyber.kepco.co.kr/ckepco/front/jsp/CY/E/E/CYEEHP00202.jsp (accessd on 09 May 2018). 